\title{
PENGARUH KUALITAS BAHAN BAKU DAN RASIO UMPAN TERHADAP PELARUT PADA PROSES PEMURNIAN GARAM DENGAN METODE HIDROEKSTRAKSI BATCH
}

\author{
Angela Martina, Judy Retti Witono, Ginajar Karya Pamungkas, Willy \\ Program Studi Teknik Kimia, Fakultas Teknologi Industri, Universitas Katolik Parahyangan \\ Jalan Ciumbuleuit 94, Bandung, 40141, Indonesia \\ Email : angela.martina@unpar.ac.id
}

\begin{abstract}
Abstrak
Indonesia masih memenuhi kebutuhan garam industrinya dengan impor garam, terutama dari Australia. Kualitas garam lokal yang dihasilkan di Indonesia yang masih belum dapat memenuhi standar garam industri masih menjadi salah satu kendala. Berbagai proses pemurnian garam hingga saat ini masih terus dikembangkan untuk dapat meningkatkan kualitas garam di Indonesia. Pada penelitian ini, proses pemurnian garam dilakukan dengan metode hidroekstrasi secara batch. Pada proses hidroekstraksi batch ini, kristal garam rakyat $\mathrm{K} 1, \mathrm{~K} 2$, dan $\mathrm{K} 3$ dikontakkan dengan larutan garam murni jenuh dengan variasi rasio umpan terhadap pelarut (F:S) 1:30; 1:35; 1:40; 1:45; dan 1:50 dan kecepatan pengadukan $50 \mathrm{rpm}$. Kualitas garam hasil pemurnian dianalisis berdasarkan kadar $\mathrm{NaCl}, \mathrm{Ca}^{2+}$, dan $\mathrm{Mg}^{2+}$. Kadar $\mathrm{NaCl}$ tertinggi, yaitu 98,89\% diperoleh pada proses menggunakan bahan baku kristal garam K2 dengan perbandingan F:S 1:45.
\end{abstract}

Kata kunci : garam, pemurnian, hidroekstraksi, batch

\begin{abstract}
Nowadays, Indonesia is still relying on the imported salt, especially from Australia to meet the domestic salt demand. Development of salt purification process is still ventured to improve the quality of the salt as well as the efficiency. In this research, salt purification process is done using the hydroextraction method, where the salt crystals are purified using the pure saturated salt solution in a beaker glass. Different classification of salt K1, K2, and K3 are used with F:S ratio is varied by 1:30; 1:35; 1:40; 1:45; and 1:50. The hydroectraction process is stirred at $50 \mathrm{rpm}$. The quality of the purified salt are determined based on analysis of the levels of $\mathrm{NaCl}, \mathrm{Ca}^{2+}$, and $\mathrm{Mg}^{2+}$. The highest $\mathrm{NaCl}$ level, 98,89\% obtained on the process using $\mathrm{K} 2$ salt with $F: S$ ratio is 1:45.
\end{abstract}

Keywords : salt, purification, hydroextraction, batch

\section{Pendahuluan}

Garam $(\mathrm{NaCl})$ merupakan salah satu komoditi besar Indonesia. Sebagai pemilik garis pantai terpanjang keempat di dunia, Indonesia memiliki modal untuk memproduksi dan memenuhi kebutuhan garam nasional secara mandiri, baik untuk kebutuhan konsumsi maupun industri. Produksi garam nasional Indonesia mencapai 60 ton/Ha/tahun dari lahan seluas 5.116 Ha yang dikelola PT. Garam, sedangkan lahan seluas $25.542 \mathrm{Ha}$ yang dikelola secara tradisional oleh rakyat hanya dapat memproduksi 40 ton/Ha/tahun [5]. Teknologi evaporasi air laut yang diterapkan oleh petani garam di Indonesia hingga saat ini hanya mampu menghasilkan garam dengan kadar $\mathrm{NaCl} 85-95 \%$ [6].

Kualitas garam rakyat ini masih belum dapat memenuhi standar kualitas garam industri yang membutuhkan garam dengan kadar 98,5\% sehingga Indonesia masih memenuhi kebutuhan garam industri dari impor garam. Standar Nasional Indonesia (SNI) garam industri dapat dilihat pada Tabel 1. Impor garam nasional dari tahun 20032013 dapat dilihat pada Tabel 2. Untuk itu, diperlukan teknologi pemurnian lebih lanjut untuk dapat meningkatkan kualitas garam rakyat.

Tabel 1. SNI garam industri [5]

\begin{tabular}{|l|c|}
\hline \multicolumn{1}{|c|}{ Parameter } & Kadar (\%) \\
\hline $\mathrm{NaCl}$ & min. 98,5 \\
\hline $\mathrm{SO}_{4}^{2-}$ & maks. 0,2 \\
\hline $\mathrm{Mg}^{2+}$ & maks. 0,06 \\
\hline $\mathrm{Ca}^{2+}$ & maks. 0,1 \\
\hline Partikel tak larut & - \\
\hline $\mathrm{H}_{2} \mathrm{O}$ & maks. 3 \\
\hline
\end{tabular}

Tabel 2. Impor garam nasional [5]

\begin{tabular}{|c|c|}
\hline Tahun & Impor (Ton) \\
\hline 2009 & 1.700 .000 \\
\hline 2010 & 2.080 .000 \\
\hline 2011 & 2.830 .000 \\
\hline 2012 & 2.220 .000 \\
\hline 2013 & 1.920 .000 \\
\hline
\end{tabular}

Hingga saat ini, teknologi pemurnian garam yang dikembangkan di Indonesia umumnya melibatkan proses pencucian, pelarutan, pengendapan, evaporasi, dan kristalisasi, di mana 
proses-proses ini membutuhkan bahan kimia tambahan untuk dapat mereduksi pengotor di dalam kristal garam. Selain itu, diperlukan pula energi panas yang cukup besar untuk dapat merekristalisasi garam. KREBBS Swiss memulai teknologi pemurnian garam dengan metode hidroekstraksi. Pada proses hidroekstraksi ini, kristal garam dicuci menggunakan larutan garam murni jenuh. Bahan baku berupa kristal garam yang masih segar dikontakkan menggunakan larutan garam murni jenuh secara kontinu, sehingga pengotor dalam kristal garam dapat ikut melarut bersama larutan garam murni jenuh sedangkan kristal garam tidak ikut melarut. Teknologi ini memungkinkan pemurnian garam dengan perpindahan massa dan energi yang lebih efisien. Hilang garam pada proses pencucian umumnya mencapai $10-40 \% \quad[4,10]$, namun proses hidroekstraksi mampu mereduksi hilang garam hingga $1-2 \%$ saja $[10,11]$. Energi panas pun hanya dibutuhkan untuk proses pengeringan saja karena garam hasil pemurnian sudah berupa kristal.

\section{Teori}

$\mathrm{NaCl}$ merupakan garam yang paling banyak ditemukan di dunia. $\mathrm{NaCl}$ murni berbentuk kristal kubik berwarna putih dengan sifat fisik seperti pada Tabel 3. NaCl dapat diperoleh dari air laut, batuan garam, atau larutan garam alamiah. Umumnya $\mathrm{NaCl}$ mengandung pengotor berupa magnesium sulfat, magnesium klorida, kalsium sulfat, kalsium klorida, dan air. Pengotor di permukaan kristal umumnya direduksi dengan proses pencucian, baik menggunakan air maupun larutan garam jenuh. Sedangkan pengotor yang terjebak di dalam kristal umumnya direduksi dengan proses pelarutan, penambahan bahan pengikat pengotor, dan rekristalisasi.

Tabel 3. Sifat fisik NaCl murni [5]

\begin{tabular}{|l|c|}
\hline \multicolumn{1}{|c|}{ Parameter } & 58,44 \\
\hline Massa molekul, g/mol & kubik \\
\hline Bentuk kristal & $\begin{array}{c}\text { tidak berwarna- } \\
\text { putih }\end{array}$ \\
\hline Warna & 1,5442 \\
\hline Refraksi indeks & 2,165 \\
\hline Densitas, g/mL & 801 \\
\hline Titik leleh, ${ }^{\circ} \mathrm{C}$ & 1413 \\
\hline Titik didih, ${ }^{\circ} \mathrm{C}$ & 2,5 \\
\hline Kekerasan, skala Mohs' & 0,853 \\
\hline Kapasitas panas, J/g. ${ }^{\circ} \mathrm{C}$ & 517,1 \\
\hline Panas peleburan, $\mathrm{J} / \mathrm{g}$ & 3,757 \\
\hline Panas pelarutan, $1 \mathrm{~kg} \mathrm{H}{ }_{2} \mathrm{O}, 25^{\circ} \mathrm{C}, \mathrm{kJ} / \mathrm{mol}$ & 75,3 \\
\hline Kelembaban kritik pada $20{ }^{\circ} \mathrm{C}, \%$ & \\
\hline
\end{tabular}

$\mathrm{NaCl}$ banyak dimanfaatkan, baik dalam bidang industri maupun konsumsi. Industri-industri yang banyak memanfaatkan $\mathrm{NaCl}$ antara lain industri tekstil, perminyakan, metalurgi, penyamakan kulit, pengolahan air, industri pembuatan natrium sulfat $\left(\mathrm{Na}_{2} \mathrm{SO}_{4}\right)$, natrium karbonat $\left(\mathrm{Na}_{2} \mathrm{CO}_{3}\right)$, natrium bikarbonat $\left(\mathrm{NaHCO}_{3}\right)$, dan industri klor alkali, yaitu industri yang menghasilkan klorin dan natrium hidroksida. Industri farmasi memanfaatkan $\mathrm{NaCl}$ dengan kemurnian tinggi (>99\%) sebagai reagen dalam analisis laboratorium.

Untuk kebutuhan konsumsi rumah tangga, garam dapur dimanfaatkan sebagai bahan peningkat rasa makanan. Garam ditambahkan zat aditif berupa Kalium Iodida (KI) dan Kalium Iodat $\left(\mathrm{KIO}_{3}\right)$. Selain itu, garam dapat pula digunakan sebagai pengawet, penguat warna, bahan pembentuk tekstur, dan bahan pengontrol fermentasi.

Di Indonesia, garam rakyat dihasilkan secara tradisional melalui proses evaporasi air laut dengan bantuan cahaya matahari. Garam rakyat ini dapat diklasifikasikan menjadi garam $\mathrm{K} 1, \mathrm{~K} 2$, dan K3. Garam K1 merupakan garam hasil proses kristalisasi pada larutan $26-29,5^{\circ} \mathrm{Be}$. Garam K1 memiliki kadar $\mathrm{NaCl}$ minimum $97,1 \%$ dan kadar air maksimum 4\%. Garam K2 merupakan garam dengan kualitas lebih rendah daripada K1. Garam ini merupakan sisa kristalisasi pada konsentrasi larutan 29,5 - 35 $5^{\circ} \mathrm{Be}$ dan memiliki kadar $\mathrm{NaCl}$ minimum 94,7\% dan kadar air maksimum 5\%. Secara fisik, garam K2 berwarna kecoklatan. Garam K3 merupakan garam kualitas terendah. Garam ini merupakan sisa kristalisasi pada konsentrasi larutan di atas $35^{\circ} \mathrm{Be}$ dan memiliki kadar $\mathrm{NaCl}$ kurang dari 94,7\% dan kadar air lebih dari 5\%. Secara fisik, garam K3 berwarna coklat dan masih bercampur lumpur [5].

Beberapa penelitian yang pernah dilakukan umumnya melibatkan proses pengendapan $\mathrm{Ca}^{2+}$ dan $\mathrm{Mg}^{2+}$ menggunakan bahan pengikat $[3,6,8,9,12,13]$. Kristal garam kotor dilarutkan, kemudian berbagai bahan pengikat pengotor $\left(\mathrm{NaOH}, \mathrm{NaH}, \mathrm{Na}_{2} \mathrm{CO}_{3}, \mathrm{NaHCO}_{3}\right.$, dan $\mathrm{Na}_{2} \mathrm{C}_{2} \mathrm{O}_{4}$ ) ditambahkan ke dalam larutan garam kotor untuk mengendapkan pengotor $\left(\mathrm{Ca}^{2+}\right.$ dan $\mathrm{Mg}^{2+}$ ). Endapan pengotor kemudian dapat difiltrasi untuk memisahkannya dari larutan garam bersihnya. Selanjutnya, larutan garam yang sudah bersih diuapkan kembali untuk mendapatkan kristal garam yang lebih murni. Proses penguapan dan kristalisasi ini membutuhkan energi panas yang cukup besar.

Proses pemurnian garam dengan hidroekstraksi memanfaatkan sifat kelarutan $\mathrm{NaCl}$ sebagai komponen utama dari garam. Dalam proses ini, pelarut yang digunakan bukan air, melainkan larutan garam $(\mathrm{NaCl})$ murni jenuh. Larutan garam murni jenuh inilah yang dapat mengekstrak pengotor dari dalam kristal garam. Pengotor utama 
dalam garam yang berupa $\mathrm{Ca}^{2+}$ dan $\mathrm{Mg}^{2+}$ akan ikut melarut bersama larutan garam jenuh, sedangkan garam $(\mathrm{NaCl})$ tidak akan ikut melarut. Proses pemisahan antara kristal garam hasil hidroekstraksi dengan larutan garam murni jenuh selanjutnya dapat dengan mudah dilakukan secara filtrasi. Energi panas pun tidak diperlukan untuk proses rekristalisasi sebagaimana dibutuhkan pada pemurnian menggunakan bahan pengendap. Panas hanya diperlukan untuk proses pengeringan kristal garam saja.

Proses pemurnian garam yang mengaplikasikan metode hidroekstraksi adalah proses SALEX (KREBBS Swiss) [10, 11]. Pengotor yang tak larut, seperti debu dan pasir yang ikut mengkristal dalam garam direduksi secara hydromilling, dimana kristal garam dihancurkan dan dicuci menggunakan larutan garam murni jenuh, sehingga pengotor yang tak larut yang erjebak di dalam kristal dapat keluar dan ikut terbawa dalam larutan garam murni jenuh. Sedangkan pengotor terlarut (terutama $\mathrm{Ca}^{2+}$ dan $\mathrm{Mg}^{2+}$ ) direduksi dengan proses pencucian. Kristal garam dikontakkan dengan larutan garam murni jenuh yang dialirkan secara counter current. Proses ini dapat mereduksi pengotor tak larut maupun terlarut di permukaan dan di dalam kristal garam hingga menghasilkan garam dengan kemurnian 99,7-99,8\% NaCl.

Pemurnian garam dengan metode hidroekstraksi secara batch mampu menurunkan $78,21 \% \mathrm{Ca}^{2+}$ dan $76,09 \% \mathrm{Mg}^{2+}$ dengan kadar $\mathrm{NaCl}$ maksimum 98,34\% [1]. Pada percobaan ini, kristal garam yang digunakan adalah kristal garam rakyat K3 dengan ukuran partikel kasar, -10+20 mesh, dan $-20+30$ mesh. Kristal garam dikontakkan dengan larutan garam murni jenuh ( $\mathrm{F}: \mathrm{S}=1: 10,1: 20,1: 30)$ di dalam gelas kimia tanpa pengaduk. Proses hidroekstraksi kemudian dilakukan selama 10, 30, dan 60 menit. Kadar $\mathrm{NaCl}$ maksimum diperoleh pada percobaan dengan ukuran partikel kristal garam K3 -20+30 mesh, F:S = 1:20, dan waktu hidroekstraksi 30 menit.

\section{Metodologi Penelitian}

Pada penelitian ini, pemurnian garam dilakukan menggunakan proses hidroekstraksi secara batch. Kristal garam yang akan dimurnikan dikontakkan menggunakan larutan garam murni jenuh (larutan pengekstrak) dalam gelas kimia 5L dengan kecepatan pengadukan $50 \mathrm{rpm}$ pada temperatur dan tekanan ruang. Proses ini memungkinkan pengotor dalam kristal garam tereduksi tanpa membuat kristal garam ikut melarut, sehingga proses pemisahan dan pengeringan kristal garam hasil pemurnian pun akan lebih mudah dilakukan.

Bahan baku yang digunakan pada penelitian ini adalah garam rakyat $\mathrm{K} 1, \mathrm{~K} 2$, dan $\mathrm{K} 3$ dengan ukuran $-2,5+5$ mesh. Perbandingan F:S divariasikan $1: 30 ; 1: 35 ; 1: 40 ; 1: 45$; dan 1:50. Analisis garam bahan baku (garam rakyat) dan garam hasil hidroekstraksi mengacu pada metode analisis standar SNI 01-3556-2000 dan ASTM E534-98. Kualitas garam dinyatakan dalam persentase kadar $\mathrm{NaCl}, \mathrm{Ca}^{2+}$, dan $\mathrm{Mg}^{2+}$. Analisis kadar $\mathrm{NaCl}$ dilakukan menggunakan atomic absorption spectrophotometer (AAS), sedangkan analisis kadar $\mathrm{Ca}^{2+}$ dan $\mathrm{Mg}^{2+}$ dilakukan menggunakan titrasi kompleksometri.

\section{Hasil dan Pembahasan}

Garam yang digunakan sebagai bahan baku pada penelitian ini merupakan garam rakyat $\mathrm{K} 1$, K2, dan K3. Ketiga kualitas garam rakyat ini diayak sehingga diperoleh partikel garam berukuran seragam $-2,5+5$ mesh. Pada penelitian ini dipilih partikel garam dengan ukuran yang cukup besar, yaitu $-2,5+5$ mesh. Ukuran ini mendekati ukuran partikel garam lokal yang diproduksi oleh petani garam di Indonesia. Setelah diperoleh ukuran partikel garam yang segaram, kristal garam dikeringkan dalam oven dengan temperatur $110^{\circ} \mathrm{C}$ selama 24 jam.

Analisis bahan baku garam K1, K2, K3 dan garam industri murni meliputi analisis kadar $\mathrm{NaCl}, \mathrm{Ca}^{2+}$, dan $\mathrm{Mg}^{2+}$. Tabel 4 menunjukkan hasil analisis kadar $\mathrm{NaCl}, \mathrm{Ca}^{2+}$, dan $\mathrm{Mg}^{2+}$ garam $\mathrm{K} 1, \mathrm{~K} 2$, $\mathrm{K} 3$, dan garam industri murni serta perbandingannya dengan SNI.

Tabel 4. Hasil analisis perbandingan $\mathrm{NaCl}, \mathrm{Ca}^{2+}$, dan $\mathrm{Mg}^{2+}$ garam rakyat serta garam industri murni dengan SNI

\begin{tabular}{|c|c|c|c|}
\hline Parameter & Jenis Garam & Hasil Analisis & $\begin{array}{l}\text { SNI Garam } \\
\text { Industri }\end{array}$ \\
\hline \multirow{4}{*}{$\begin{array}{c}\text { Kadar } \mathrm{NaCl} \\
(\% b)^{*}\end{array}$} & $\mathrm{~K} 1$ & 93,62 & \multirow{4}{*}{$\min .98,5$} \\
\hline & $\mathrm{K} 2$ & 92,11 & \\
\hline & $\mathrm{K} 3$ & 91,5 & \\
\hline & Industri & 98,9 & \\
\hline \multirow{4}{*}{$\begin{array}{c}\text { Kadar } \mathrm{Ca}^{2+} \\
(\% \mathrm{~b})^{* *}\end{array}$} & $\mathrm{~K} 1$ & 0,84 & \multirow{4}{*}{ maks. 0,1} \\
\hline & $\mathrm{K} 2$ & 1,06 & \\
\hline & K3 & 1,8 & \\
\hline & Industri & 0,09 & \\
\hline \multirow{4}{*}{$\begin{array}{c}\text { Kadar } \mathrm{Mg}^{2+} \\
(\% \mathrm{~b})^{* *}\end{array}$} & K1 & 1,09 & \multirow{4}{*}{ maks. 0,06} \\
\hline & $\mathrm{K} 2$ & 1,73 & \\
\hline & K3 & 4,37 & \\
\hline & Industri & 0,06 & \\
\hline
\end{tabular}

*) Analisis menggunakan atomic absorption spectroscopy (AAS)

**) Analisis menggunakan metode titrasi kompleksometri

Berdasarkan hasil analisis, kualitas garam $\mathrm{K} 1$, K2, dan K3 belum memenuhi SNI, sedangkan garam industri murni yang akan digunakan sebagai larutan pengekstrak dalam porses hidroekstraksi 
sudah memenuhi SNI. Diharapkan garam K1, K2, dan K3 yang akan dimurnikan dengan metode hidroektraksi ini memiliki standar kualitas SNI.

Proses hidroekstraksi dilakukan dengan mengontakkan kristal garam K3 dengan larutan garam industri murni jenuh (larutan pengekstrak) di dalam gelas kimia 5L dengan kecepatan pengadukan $50 \mathrm{rpm}$. Berdasarkan hasil penelitian sebelumnya, kecepatan pengandukan dalam proses hidroekstraksi ini tidak berpengaruh signifikan, sehingga pada penelitian ini dipilih kecepatan pengadukan terendah, yaitu $50 \mathrm{rpm}$ [2]. Variasi yang dilakukan pada penelitian ini meliputi variasi kualitas bahan baku garam K1, K2, dan K3 serta variasi F:S 1:30, 1:35, 1:40, 1:45, 1:50. Proses hidroekstraksi dilakukan hingga kadar $\mathrm{Ca}^{2+}$ dan $\mathrm{Mg}^{2+}$ di dalam larutan pengekstrak sudah konstan. Pada kondisi ini dianggap proses telah mencapat kesetimbangan dimana sudah tidak ada perpindahan massa dari kristal garam ke larutan pengekstrak. Kualitas garam hasil hidroekstraksi dapat dilihat pada Tabel 5.

Tabel 5. Kualitas garam hasil hidroekstraksi

\begin{tabular}{|c|c|c|c|c|c|c|}
\hline \multirow{2}{*}{$\begin{array}{c}\text { Kualitas } \\
\text { bahan } \\
\text { baku }\end{array}$} & \multirow[b]{2}{*}{$\mathrm{F}: \mathrm{S}$} & \multicolumn{5}{|c|}{ Kualitas garam hasil hidroekstraksi } \\
\hline & & $\begin{array}{c}\text { Kadar } \\
\mathrm{Ca}^{2+} \\
(\%) \\
\end{array}$ & $\begin{array}{c}\text { Kadar } \\
\mathrm{Mg}^{2+} \\
(\%)\end{array}$ & $\underset{\mathrm{Ca}^{2+}}{\text { \%penurunan }}$ & $\begin{array}{c}\text { \%penurunan } \\
\mathrm{Mg}^{2+}\end{array}$ & $\begin{array}{c}\text { Kadar } \\
\mathrm{NaCl} \\
(\%) \\
\end{array}$ \\
\hline \multirow{5}{*}{ K1 } & $1: 30$ & 0,21 & 0,06 & 75,00 & 94,50 & 96,00 \\
\hline & $1: 35$ & 0,11 & 0,19 & 86,90 & 82,57 & 96,88 \\
\hline & $1: 40$ & 0,21 & 0,06 & 75,00 & 94,50 & 98,64 \\
\hline & $1: 45$ & 0,11 & 0,10 & 86,90 & 90,83 & 96,19 \\
\hline & $1: 50$ & 0,11 & 0,06 & 86,90 & 94,50 & 96,58 \\
\hline \multirow{5}{*}{$\mathrm{K} 2$} & $1: 30$ & 0,32 & 0,19 & 69,81 & 89,02 & 94,13 \\
\hline & $1: 35$ & 0,32 & 0,13 & 69,81 & 92,49 & 95,12 \\
\hline & $1: 40$ & 0,42 & 0,10 & 60,38 & 94,22 & 97,36 \\
\hline & $1: 45$ & 0,21 & 0,26 & 80,19 & 84,97 & 98,89 \\
\hline & $1: 50$ & 0,32 & 0,19 & 69,81 & 89,02 & 97,94 \\
\hline \multirow{5}{*}{ K3 } & $1: 30$ & 0,85 & 0,74 & 52,78 & 83,07 & 92,20 \\
\hline & $1: 35$ & 0,53 & 0,19 & 70,56 & 95,65 & 94,54 \\
\hline & $1: 40$ & 0,48 & 0,32 & 73,33 & 92,68 & 95,64 \\
\hline & $1: 45$ & 0,37 & 0,19 & 79,44 & 95,65 & 96,69 \\
\hline & $1: 50$ & 0,42 & 0,29 & 76,67 & 93,36 & 96,78 \\
\hline
\end{tabular}

Berdasarkan hasil analisis pada Tabel 5, rata-rata penurunan $\mathrm{Ca}^{2+}$ pada garam $\mathrm{K} 1, \mathrm{~K} 2$, dan $\mathrm{K} 3$ cenderung lebih kecil dibandingkan penurunan $\mathrm{Mg}^{2+}$. Kandungan $\mathrm{Ca}^{2+}$ dalam bahan baku garam $\mathrm{K} 1, \mathrm{~K} 2$, dan $\mathrm{K} 3$ lebih sedikit dibandingan dengan kandungan $\mathrm{Mg}^{2+}$. Dalam larutan garam murni jenuh yang digunakan sebagai larutan pengekstrak pun kadar $\mathrm{Ca}^{2+}$ yang terkandung di dalamnya sangat sedikit. Hal ini mengakibatkan perbedaan konsentrasi $\mathrm{Ca}^{2+}$ dalam larutan pengekstrak dan kristal garam K1, K2, dan K3 lebih kecil dibandingkan perbedaan konsentrasi $\mathrm{Mg}^{2+}$. Oleh karena perbedaan konsentrasi yang menjadi driving force perpindahan massa $\mathrm{Ca}^{2+}$ dari kristal garam ke dalam larutan pengekstrak menjadi lebih kecil, maka rata-rata penurunan $\mathrm{Ca}^{2+}$ menjadi lebih kecil dibandingkan rata-rata penurunan $\mathrm{Mg}^{2+}$.

Kualitas bahan baku yang berbeda pun menghasilkan garam dengan kualitas yang berbeda pula. Semakin tinggi kualitas bahan baku semakin tinggi pula kemurnian garam yang dihasilkan. Rata-rata kadar $\mathrm{Ca}^{2+}$ dan $\mathrm{Mg}^{2+}$ yang tersisa pada garam K1 $(0,15 \%)$ paling rendah dibandingkan dengan kadar $\mathrm{Ca}^{2+}$ dan $\mathrm{Mg}^{2+}$ yang tersisa pada garam K2 $(0,32 \%)$ dan K3 $(0,53 \%)$. Rata-rata kadar $\mathrm{NaCl}$ yang diperoleh pada garam $\mathrm{K} 1$ pun paling tinggi, yaitu 96,86\%. Gambar 1 menunjukkan kadar $\mathrm{NaCl}$ rata-rata garam hasil hidroekstraksi pada berbagai kualitas garam.

Kadar $\mathrm{Ca}^{2+}$ dan $\mathrm{Mg}^{2+}$ pada garam $\mathrm{K} 1$ yang memang sudah lebih sedikit dibandingkan dengan garam $\mathrm{K} 2$ dan $\mathrm{K} 3$ mengakibatkan massa pengotor $\left(\mathrm{Ca}^{2+}\right.$ dan $\left.\mathrm{Mg}^{2+}\right)$ yang harus berpindah dari kristal garam ke dalam pengekstrak menjadi lebih sedikit sehingga larutan pengekstrak masih mampu mereduksi pengotor tersebut. Pada kualitas garam yang lebih rendah (K2 dan $\mathrm{K} 3$ ), massa $\mathrm{Ca}^{2+}$ dan $\mathrm{Mg}^{2+}$ yang terkandung di dalamnya lebih banyak, sehingga larutan pengektrak pun harus mereduksi pengotor lebih banyak. Larutan pengektrak dapat mereduksi $\mathrm{Ca}^{2+}$ dan $\mathrm{Mg}^{2+}$ hingga batas jenuhnya. Seiring berjalannya proses hidroekstraksi, jumlah $\mathrm{Ca}^{2+}$ dan $\mathrm{Mg}^{2+}$ yang berpindah dari kristal garam ke dalam larutan pengekstrak pun semakin banyak, sehingga kecepatan perpindahan massa $\mathrm{Ca}^{2+}$ dan $\mathrm{Mg}^{2+}$ menjadi lebih lambat.

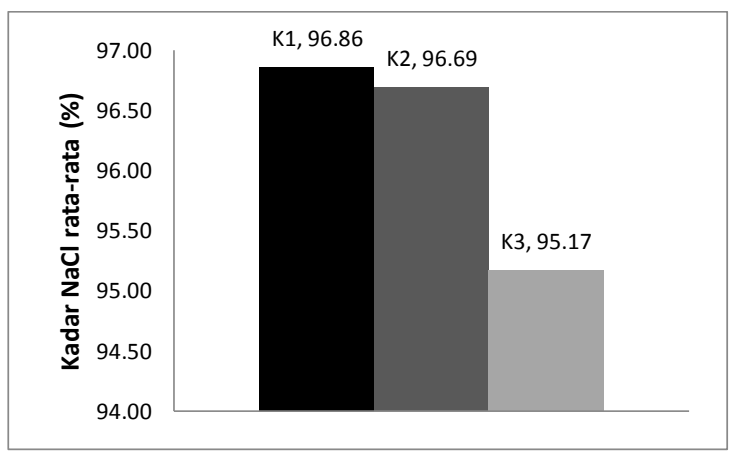

Gambar 1. Kadar NaCl rata-rata garam hasil hidroekstraksi pada berbagai kualitas garam

Berdasarkan hasil analisis pada Tabel 5, penurunan $\mathrm{Ca}^{2+}$ dan $\mathrm{Mg}^{2+}$ pada $\mathrm{F}: \mathrm{S}$ yang semakin besar cenderung lebih besar. Pada perbandingan F:S yang semakin besar, volume larutan garam jenuh yang digunakan sebagai larutan pengekstrak pun semakin besar sehingga semakin banyak massa $\mathrm{Ca}^{2+}$ dan $\mathrm{Mg}^{2+}$ yang dapat berpindah dari kristal garam ke dalam larutan pengekstrak. Akibatnya, pada akhir proses hidroekstraksi kadar $\mathrm{NaCl}$ yang 
diperoleh akan semakin besar (kemurnian garam lebih tinggi).

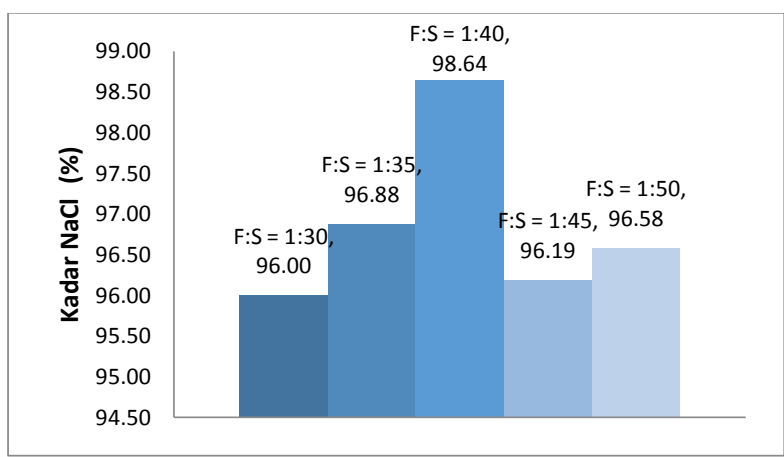

Gambar 2. Kadar $\mathrm{NaCl}$ garam hasil hidroekstraksi pada berbagai $\mathrm{F}$ :S dengan bahan baku garam $\mathrm{K} 1$

Berdasarkan hasil penelitian, kadar $\mathrm{NaCl}$ tertinggi dari setiap kualitas bahan baku diperoleh pada perbandingan $\mathrm{F}: \mathrm{S}$ yang berbeda Kadar $\mathrm{NaCl}$ tertinggi bahan baku garam $\mathrm{K} 1$ diperoleh pada $\mathrm{F}: \mathrm{S}$ $=1: 40$, sedangkan kadar $\mathrm{NaCl}$ tertinggi bahan baku garam $\mathrm{K} 2$ diperoleh pada $\mathrm{F}: \mathrm{S}=1: 45$, dan kadar $\mathrm{NaCl}$ tertinggi bahan baku garam K3 diperoleh pada $\mathrm{F}: \mathrm{S}=1: 50$. Semakin tinggi kualitas bahan baku, semakin kecil F:S yang diperlukan untuk menghasilkan garam dengan kadar $\mathrm{NaCl}$ tertinggi. Hal ini disebabkan oleh kadar pengotor $\left(\mathrm{Ca}^{2+}\right.$ dan $\mathrm{Mg}^{2+}$ ) yang terkandung di dalam bahan baku garam. Semakin tinggi kualitas garam bahan baku, semakin sedikit massa $\mathrm{Ca}^{2+}$ dan $\mathrm{Mg}^{2+}$ yang masih terkandung di dalamnya, sehingga larutan pengekstrak dapat mereduksi $\mathrm{Ca}^{2+}$ dan $\mathrm{Mg}^{2+}$ hanya dengan volume yang sedikit. Sebaliknya, semakin rendah kualitas garam bahan baku semakin banyak massa $\mathrm{Ca}^{2+}$ dan $\mathrm{Mg}^{2+}$ yang harus direduksi sehingga dibutuhkan lebih banyak larutan pengekstrak (F:S lebih besar). Akibatnya, untuk memperoleh garam dengan kemurnian yang tinggi (kadar $\mathrm{NaCl}$ tinggi) diperlukan $\mathrm{F}: \mathrm{S}$ yang lebih besar. Kadar $\mathrm{NaCl}$ pada berbagai $\mathrm{F}: \mathrm{S}$ dapat dilihat pada gambar 2, gambar 3, dan gambar 4.

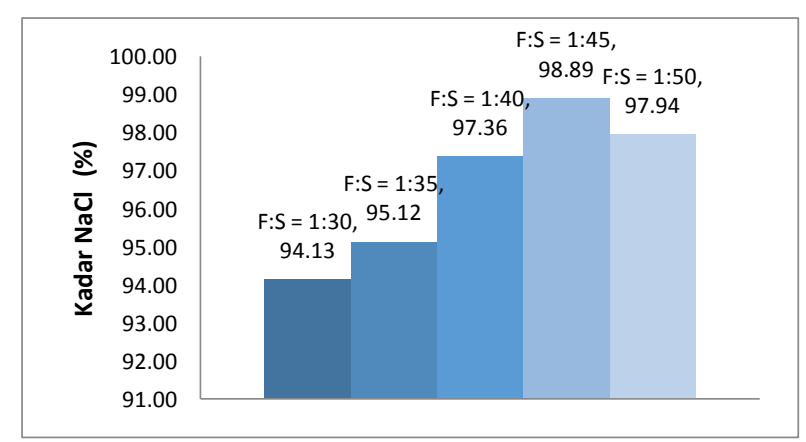

Gambar 3. Kadar NaCl garam hasil hidroekstraksi pada berbagai $\mathrm{F}$ :S dengan bahan baku garam $\mathrm{K} 2$

Berdasarkan gambar 4, kadar $\mathrm{NaCl}$ garam hasil hidroekstraksi cenderung semakin bertambah seiring peningkatan F:S. Hingga perbandingan F:S $=1: 50$, kadar $\mathrm{NaCl}$ yang diperoleh mencapai
96,78\%. Garam hasil hidroekstraksi ini memang masih belum memenuhi SNI. Namun, dari profil peningkatan kadar $\mathrm{NaCl}$ terhadap $\mathrm{F}: \mathrm{S}$ tersebut, masih dimungkinkan terjadi peningkatan kadar $\mathrm{NaCl}$ jika F:S ditingkatkan. Masih perlu dilakukan penelitian dengan peningkatan $\mathrm{F}: \mathrm{S}$ untuk mengetahui sejauh mana kadar $\mathrm{NaCl}$ masih dapat terus meningkat seiring peningkatan F:S.

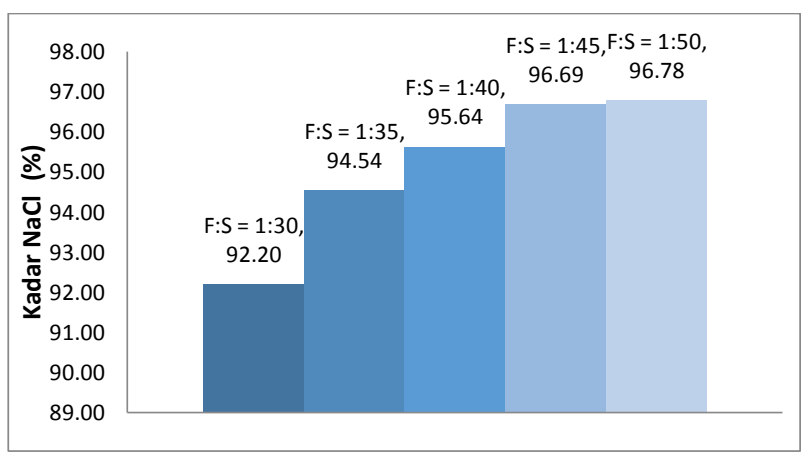

Gambar 4. Kadar NaCl garam hasil hidroekstraksi pada berbagai $\mathrm{F}$ :S dengan bahan baku garam $\mathrm{K3}$

Kualitas garam hasil hidroekstraksi batch dibandingkan dengan kualitas garam industri murni yang ada di pasaran dan SNI. Analisis dilakukan berdasarkan uji visual (warna), analisis kadar $\mathrm{NaCl}$, $\mathrm{Ca}^{2+}$ dan $\mathrm{Mg}^{2+}$. Tabel 6menunjukkan perbandingan kualitas garam hasil hidroekstraksi batch dengan standar pasar dan SNI.

Tabel 6. Perbandingan kualitas garam hasil hidroekstraksi batch dengan SNI dan standar pasar

\begin{tabular}{|l|c|c|c|}
\hline & $\begin{array}{c}\text { Hasil } \\
\text { hidroekstraksi }\end{array}$ & SNI & $\begin{array}{c}\text { Standar } \\
\text { pasar }\end{array}$ \\
\hline Warna & $\begin{array}{c}\text { putih } \\
\text { kecoklatan }\end{array}$ & putih & putih \\
\hline $\mathrm{NaCl}(\%)$ & $92.20-98.89$ & min. 98,5 & 98.9 \\
\hline $\mathrm{Ca}^{2+}(\%)$ & $0.11-0.85$ & maks. 0.1 & 0.09 \\
\hline $\mathrm{Mg}^{2+}(\%)$ & $0.06-0.74$ & maks. 0.06 & 0.06 \\
\hline
\end{tabular}

Berdasarkan Tabel 6, secara umum kualitas garam hasil hidroekstraksi batch masih belum memenuhi standar SNI, dimana kualitas garam industri harus memenuhi minal keempat parameter uji tersebut. Berdasarkan uji visual, kristal garam hasil hidroesktraksi masih berwarna putih kecoklatan. Hal ini menunjukkan bahwa masih ada pengotor tak larut berupa debu atau lumpur yang masih terkandung di dalam kristal garam. Kadar $\mathrm{NaCl}$ tertinggi $(98,89 \%)$ yang diperoleh sudah hampir memenuhi SNI, namun kadar $\mathrm{Ca}^{2+}$ dan $\mathrm{Mg}^{2+}$ pada run penelitian yang bersangkutan masih di atas SNI, sehingga garam masih dikatakan belum memenuhi SNI. Demikian pula pada kadar $\mathrm{Mg}^{2+}$ yang sudah memenuhi SNI $(0,06 \%)$, kadan $\mathrm{NaCl}$ dan $\mathrm{Ca}^{2+}$ pada run penelitian yang bersangkutan masih di atas SNI. Namun 
proses hidroekstraksi batch ini dapat menurunkan $86,90 \%$ kadar $\mathrm{Ca}^{2+}$ dan $95,65 \%$ kadar $\mathrm{Mg}^{2+}$.

\section{Kesimpulan}

Proses hidroekstraksi menghasilkan penurunan rata-rata $\mathrm{Ca}^{2+}$ sebesar $86,90 \%$ dan $\mathrm{Mg}^{2+}$ sebesar 95,65\%. Proses hidroekstraksi dapat meningkatkan kualitas garam rakyat $\mathrm{K} 1$ dan $\mathrm{K} 2$ menjadi garam SNI. Kemurnian $\mathrm{NaCl}$ tertinggi diperoleh saat menggunakan bahan baku garam K2 pada variasi percobaan $\mathrm{F}: \mathrm{S}$ dengan perbandingan 1:45, yaitu sebesar 98,89\%. Penelitian ini masih dapat dikembangkan dengan melakukan variasi perbandingan F:S yang lebih besar untuk mengetahui kemurnian maksimum yang dapat dicapai. Proses hidroekstraksi batch multitahap dan/atau kontinu pun dapat dilakukan untuk mengetahui seberapa efisien dan efektif proses ini dapat digunakan untuk pemurnian garam rakyat

\section{Daftar Pustaka}

[1] A. Martina, dan J. R. Witono, Pemurnian Garam dengan Metode Hidroekstraksi Batch, Prosiding The $1^{\text {st }}$ University Research Colloquium 2015 (ISSN 2407-9189), Universitas Muhammadiyah, Surakarta, 2015, p. 36-42.

[2] A. Martina, Ginanjar K.P., Willy, dan J. R. Witono, Pemurnian Garam Rakyat Melalui Proses Hidroekstraksi Secara Batch, Prosiding Seminar Nasional Teknik Kimia UNPAR 2015, Universitas Katolik Parahyangan, Bandung, 2015.

[3] D. Lesdantina, dan Istikomah, Pemurnian $\mathrm{NaCl}$ dengan Menggunakan Natrium Karbonat, Seminar Tugas Akhir S1 Teknik Kimia UNDIP 2009, Semarang, http:// eprints.undip.ac.id/1337/1/paper_isti_mahda pdf.pdf, diakses pada 6 September 2011.

[4] D. Wilarso, Peningkatan Kadar $\mathrm{NaCl}$ pada Proses Pencucian Garam Rakyat di Pabrik, Buletin Penelitian dan Pengembangan Industri No.21, Agustus 1996, 23-26, http:// isjd.pdii.lipi.go.id/admin/jurnal/21962326.pdf, diakses pada 20 September 2012.

[5] Kementrian Kelautan dan Perikanan, Panduan Pengembangan Usaha Terpadu Garam dan Artemia, Pusat Riset Wilayah Laut dan Sumberdaya Non Hayati Badan Riset Kelautan dan Perikanan Departemen Kelautan dan Perikanan, 2007.

[6] Kusnarjo, Pengurangan Kadar $\mathrm{Mg}^{2+}$ di Dalam Garam Rakyat dengan Proses Unggun
Terfluidisasi, Prosiding Seminar Nasional Rekayasa Kimia dan Proses 2000, Semarang, 2000, p. A21-A27.

[7] Othmer, K., Encyclopedia of Chemical Technology, $2^{\text {nd }}$ ed., Vol 18, John Wiley and Sons Inc., USA, 1969.

[8] T. Sulistyaningsih, W. Sugiyo, dan S. M. R. Sedyawati, Pemurnian Garam Dapur Melalui Metode Kristalisasi Air Tua dengan Bahan Pengikat Pengotor $\mathrm{Na}_{2} \mathrm{C}_{2} \mathrm{O}_{4}-\mathrm{NaHCO}_{3}$ dan $\mathrm{Na}_{2} \mathrm{C}_{2} \mathrm{O}_{4}-\mathrm{Na}_{2} \mathrm{CO}_{3}$, http://journal.unnes.ac.id/ nju/index.php/sainteknol/article/download/33 5/319, 2010, diakses pada 6 September 2011.

[9] V. A. Mayasari, dan R. Lukman, Studi Peningkatan Mutu Garam dengan Pencucian, http://digilib.its.ac.id/public/ITS-

Undergraduate-10536-Paper.pdf, 2011, diakses pada 13 Oktober 2011.

[10] V. M. Sedivy, Environmental Balance Of Slat Production Speaks in Favour Of Solar Saltworks, http://www.salt-partners.com/ pdf/Beijing2009Paper.pdf., 2006, diakses pada 3 Januari 2011.

[11] V. M. Sedivy, V.M., Processing of Salt For Chemical And Human Consumption, $9^{\text {th }}$ Symposium on Salt (ISBN 978-7-80251-2139), Vol. 2, (2010), 1385-1402, Beijing.

[12] Widayat, Production of Industry Salt with Sedimentation-Microfiltration Process : Optimization of Temperature and Concentration by Using Surface response Methodology, TEKNIK Vol. 30 No.1, (2009), 11-18, http://eprints.undip.ac.id/ 20179/1/ Widayat.pdf, diakses pada 6 September 2011.

[13] Widayat, D. S. Retnowati, F. Himawan, dan M. Widiyanti, Pembuatan garam Industri dari Air Laut Kota Rembang dengan Metode Pengandapan dan Evaporasi, Prosiding Seminar Nasional Teknik Kimia "Kejuangan" Pengembangan Teknologi Kimia untuk Pengolahan Sumber Daya Alam Indonesia, Yogyakarta, 2005. 